Jacek Kulicki

\title{
Obowiązek prowadzenia ewidencji sprzedaży przy zastosowaniu kas rejestrujących przez stowarzyszenie/ fundację
}

\author{
Obligation to keep sales records using cash registers by an association \\ or foundation
}

\begin{abstract}
The obligation to keep sales records using cash registers applies to all taxpayers of the VAT performing sale to natural persons who do not run a business and flat-rate farmers. If a non-profit organization (association, foundation) sells to these entities - despite the lack of commercial nature of the activity (sale) or including economic activity into the statute - it is obliged to keep sales records using cash registers, unless it takes benefit from an exemption resulting from the relevant executory provisions.
\end{abstract}

Keywords: foundation, tax, associations, VAT

\begin{abstract}
Obowiązek prowadzenia ewidencji sprzedaży przy zastosowaniu kas rejestrujących obejmuje wszystkich podatników podatku od towarów i usług dokonujących sprzedaży na rzecz osób fizycznych nieprowadzących działalności gospodarczej oraz rolników ryczałtowych. Jeśli organizacja non profit (stowarzyszenie, fundacja) dokonuje sprzedaży na rzecz tych podmiotów, jest obowiązana - pomimo braku zarobkowego charakteru działalności (sprzedaży) lub wpisania działalności gospodarczej do statutu - prowadzić ewidencję sprzedaży przy zastosowaniu kas rejestrujących, chyba że korzysta ze zwolnienia wynikającego z odpowiednich przepisów wykonawczych.
\end{abstract}

Słowa kluczowe: fundacja, podatek, stowarzyszenia, VAT

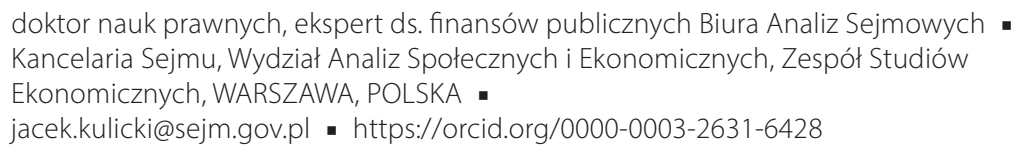

\section{Przedmiot opinii}

Przedmiotem opinii jest odpowiedź na następujące pytanie: „Czy stowarzyszenie lub fundacja prowadząc działalność statutową (jeżeli działalność gospodarcza nie jest wpisana do KRS) musi posiadać kasę fiskalną vide wystawiać paragony, jeżeli wystawia bilety płatne lub organizuje płatny letni wypoczynek dla uczestników?”.

1 Opinia prawna na temat obowiazku prowadzenia ewidencji sprzedaży przy zastosowaniu kas rejestrujacych przez stowarzyszenielfundacje sporządzona 4 lutego 2020 r. na zlecenie posła Klubu Parlamentarnego LEWICA; BAS-WASiE-118/20. 


\section{Regulacje prawne w zakresie objętym pytaniem}

W zakresie objętym pytaniem zastosowanie będą miały:

- ustawa z dnia 11 marca 2004 r. o podatku od towarów i usług (t.j. Dz.U. 2018, poz. 2174, ze zm.; dalej również: u.p.t.u.), która w art. 111-111b reguluje obowiązki i uprawnienia w zakresie prowadzenia kas rejestrujących (fiskalnych) przez podatników dokonujących sprzedaży na rzecz osób fizycznych nieprowadzących działalności gospodarczej oraz rolników ryczałtowych;

- rozporządzenie Ministra Finansów z dnia 28 grudnia 2018 r. w sprawie zwolnień z obowiązku prowadzenia ewidencji przy zastosowaniu kas rejestrujących (Dz.U. poz. 2519; dalej również: r.zwal.), które określa grupy podatników oraz czynności zwolnione z obowiązku prowadzenia ewidencji obrotu i kwot podatku należnego przy zastosowaniu kas rejestrujących.

\section{Analiza obowiązującego stanu prawnego w zakresie objętym pytaniem}

Zgodnie $\mathrm{z}$ art. 111 ust. 1 u.p.t.u.: „Podatnicy dokonujący sprzedaży na rzecz osób fizycznych nieprowadzących działalności gospodarczej oraz rolników ryczałtowych są obowiązani prowadzić ewidencję sprzedaży przy zastosowaniu kas rejestrujących". Obowiązek ten obejmuje wszystkich podatników podatku od towarów i usług dokonujących sprzedaży na rzecz podmiotów wskazanych w art. 111 ust. 1 u.p.t.u.

Zgodnie $\mathrm{z}$ art. 15 ust. 1 u.p.t.u. podatnikami tego podatku są osoby prawne, jednostki organizacyjne nieposiadające osobowości prawnej oraz osoby fizyczne wykonujące samodzielnie działalność gospodarczą zdefiniowaną w art. 15 ust. 2 u.p.t.u., bez względu na cel i rezultat takiej działalności.

W ustawie z dnia 7 kwietnia 1989 r. - Prawo o stowarzyszeniach (t.j. Dz.U.2019, poz. 713; dalej również: u.pr.st.) zdefiniowano stowarzyszenie jako dobrowolne, samorządne, trwałe zrzeszenie osób ${ }^{2}$ o celach niezarobkowych (por. art. 2 ust. 1 u.pr.st.), wyróżniając stowarzyszenia mające osobowość prawną (por. art. 17 ust. 1 u.pr.st.) oraz stowarzyszenia zwykłe, będące uproszczoną formą stowarzyszenia, nieposiadające osobowości prawnej (por. art. 40 ust. 1 u.pr.st.). Zgodnie z art. 1 ustawy z dnia 6 kwietnia 1984 r. o fundacjach (t.j. Dz.U. 2018, poz. 1491; dalej również: u.fund.): „Fundacja może być ustanowiona dla realizacji zgodnych z podstawowymi interesami Rzeczypospolitej Polskiej celów społecznie lub gospodarczo użytecznych, w szczególności takich, jak: ochrona zdrowia, rozwój gospodarki i nauki, oświata i wychowanie, kultura i sztuka, opieka i pomoc spo-

Zgodnie z art. 10 ust. 3 u.pr.st. osoba prawna może być jedynie wspierającym członkiem stowarzyszenia. 
łeczna, ochrona środowiska oraz opieka nad zabytkami”. „Fundacje mogą ustanawiać osoby fizyczne niezależnie od ich obywatelstwa i miejsca zamieszkania bądź osoby prawne mające siedziby w Polsce lub za granicą" (art. 2 ust. 1 u.fund.). Zgodnie z art. 7 ust. 2 u.fund.: „Fundacja uzyskuje osobowość prawną z chwilą wpisania do Krajowego Rejestru Sądowego".

Ustawa o podatku od towarów i usług definiuje działalność gospodarczą jako „wszelką działalność producentów, handlowców lub usługodawców, w tym podmiotów pozyskujących zasoby naturalne oraz rolników, a także działalność osób wykonujących wolne zawody", przy czym - jak wynika z dalszej części ust. 2 w art. 15 u.p.t.u. - „[d]ziałalność gospodarcza obejmuje w szczególności czynności polegające na wykorzystywaniu towarów lub wartości niematerialnych i prawnych w sposób ciągły dla celów zarobkowych". Jest to więc definicja szersza niż ta wynikająca z ustawy z dnia 6 marca 2018 r. - Prawo przedsiębiorców (t.j. Dz.U. 2019, poz. 1292, ze zm.; dalej również: u.pr.p.), zgodnie z którą działalność gospodarcza to „zorganizowana działalność zarobkowa, wykonywana we własnym imieniu i w sposób ciągły" (art. 3 u.pr.p.), przedsiębiorca zaś to „osoba fizyczna, osoba prawna lub jednostka organizacyjna niebędąca osobą prawną, której odrębna ustawa przyznaje zdolność prawną, wykonująca działalność gospodarczą" (art. 4 ust. 1 u.pr.p.), a także wspólnik spółki cywilnej w zakresie wykonywanej przez niego działalności gospodarczej (por. art. 4 ust. 2 u.pr.p.).

Jak zauważa się w literaturze przedmiotu i jak wynika wprost $\mathrm{z}$ art. 15 ust. 1 u.p.t.u., „uznanie aktywności danej osoby za działalność gospodarczą nie jest uzależnione od celu takiej działalności ani od jej rezultatu. W szczególności działalność gospodarcza nie musi być prowadzona w celu osiągnięcia zysku [...]”, co pozwala „na uznanie za podatników VAT różnego rodzaju organizacji o charakterze non profit, organów administracji publicznej, czyli wszelkich podmiotów, które nie działają w celu osiągnięcia zysku. Działalność gospodarcza w rozumieniu ustawy VAT nie musi być, bowiem działalnością o charakterze zarobkowym"3. Tym samym należy stwierdzić, że o ile organizacja non profit (stowarzyszenie, fundacja) dokonuje sprzedaży na rzecz osób fizycznych nieprowadzących działalności gospodarczej lub rolników ryczałtowych - pomimo braku zarobkowego charakteru działalności (sprzedaży) lub wpisania działalności gospodarczej do statutu - jest obowiązana prowadzić ewidencję sprzedaży przy zastosowaniu kas rejestrujących. Organizacja taka (stowarzyszenie, fundacja) jest bowiem podatnikiem podatku od towarów i usług, o ile dokonuje odpłatnej dostawy towarów i odpłatnego świadczenia usług w rozumieniu art. 5 ust. 1 pkt 1 u.p.t.u., określającego przedmiotowy zakres podatku od towarów i usług, oraz art. 7 i 8 u.p.t.u., definiujących dostawę towarów i świad-

A. Bartosiewicz, Komentarz do art. 15 ustawy o podatku od towarów i uslug, LEX, pkt 24 . 
czenie usług. Co istotne, czynności te podlegają opodatkowaniu podatkiem od towarów i usług niezależnie od tego, czy zostały wykonane z zachowaniem warunków oraz form określonych w przepisach prawa (por. art. 5 ust. 2 u.p.t.u.). Tym samym w zakresie ewidencjonowania obrotu i kwot podatku należnego mają do niej zastosowanie te same przepisy co do pozostałych podatników podatku od towarów i usług, w tym dotyczące obowiązku prowadzenia ewidencji sprzedaży przy zastosowaniu kas rejestrujących ${ }^{4}$. Wyłączenie tego obowiązku jest możliwe tylko na zasadach określonych w rozporządzeniu wydanym na podstawie art. 111 ust. 8 u.p.t.u. (r.zwal.). Rozporządzenie to określa dwie grupy wyłączeń (zwolnień) z obowiązku prowadzenia ewidencji obrotu i kwot podatku należnego przy zastosowaniu kas rejestrujących - przedmiotowe (ze względu na rodzaj towaru lub świadczonej usługi) oraz podmiotowe (ze względu na wysokość osiąganych obrotów) ${ }^{5}$.

Zgodnie $\mathrm{z} \$ 2$ ust. 1 r.zwal. z obowiązku ewidencjonowania $\mathrm{w}$ danym roku podatkowym, nie dłużej niż do 31 grudnia 2021 r., są zwolnione czynności wymienione w załączniku do tego rozporządzenia. Są to m.in. usługi w zakresie noclegów, usługi w zakresie zakwaterowania, wynajem i usługi zarządzania nieruchomościami, usługi w zakresie edukacji, usługi świadczone przez organizacje członkowskie. Te ostatnie - klasyfikowane w sekcji S w dziale 94 PKWiU $2008^{6}$ - obejmują: usługi świadczone przez organizacje komercyjne, pracodawców i profesjonalne (PKWiU 94.1), usługi świadczone przez związki zawodowe (PKWiU 94.2), usługi świadczone przez pozostałe organizacje członkowskie (PKWiU 94.9), tzn. religijne (PKWiU 94.91), polityczne (PKWiU 94.92), gdzie indziej niesklasyfikowane (PKWiU 94.99) - organizacje mające na celu ochronę praw człowieka (PKWiU 94.99.11), organizacje mające na celu ochronę środowiska (PKWiU 94.99.12), organizacje mające na celu ochronę i poprawę sytuacji pewnych specjalnych grup społecznych (PKWiU 94.99.13), usługi wspomagające działania na rzecz poprawy warunków życia ludności i inicjatyw społecznych (PKWiU 94.99.14), usługi świadczone przez związki młodzieżowe (PKWiU 94.99.15), usługi świadczone przez stowarzyszenia kulturalne i rekreacyjne (PKWiU 94.99.16), usługi świadczone przez pozostałe społeczne organizacje

4 Por. również interpretację indywidualną $\mathrm{nr}$ 0112-KDIL2-2.4012.523.2018.3.MŁ z dnia 5 lutego 2019 r., publ., nr dokumentu 548621/I, https://sip.mf.gov.pl [dostęp 3 lutego 2020 r.].

5 Zwolnienia te nie obejmują dostawy towarów i świadczenia usług określonych w $₫ 4$ r.zwal.

6 Zob. rozporządzenie Rady Ministrów z dnia 29 października 2008 r. w sprawie Polskiej Klasyfikacji Wyrobów i Usług (PKWiU), Dz.U. nr 207, poz. 1293, ze zm., stosowane dla celów podatku od towarów i usług do 31 marca 2020 r. na podstawie $₫ 3$ pkt 1 rozporządzenia Rady Ministrów z dnia 4 września 2015 r. w sprawie Polskiej Klasyfikacji Wyrobów i Usług (PKWiU), Dz.U. poz. 1676, ze zm. Por. również przypis $3 \mathrm{w}$ załączniku do r.zwal. 
członkowskie (PKWiU 94.99.17), usługi świadczone przez pozostałe organizacje członkowskie, gdzie indziej niesklasyfikowane (PKWiU 94.99.19) oraz usługi związane z przyznawaniem dotacji przez organizacje członkowskie (PKWiU 94.99.2). W tym kontekście należy zauważyć, że - zgodnie z pkt 7.6.2 Zasad metodycznych Polskiej Klasyfikacji Wyrobów i Usług (PKWiU 2008) - gdy przeprowadzona analiza opisu wykonywanych czynności wskazuje na możliwość zaliczenia usługi do dwóch lub kilku grupowań, należy przyjąć następujące zasady klasyfikacji, z tym jednak że porównywać można jedynie grupowania tego samego poziomu hierarchicznego:

- grupowanie, które zawiera bardziej dokładny opis czynności, powinno być uprzywilejowane (wybrane) w stosunku do grupowania zawierającego opis ogólny;

- usługa złożona, która składa się z kombinacji różnych czynności i której nie można zaklasyfikować zgodnie z wyżej wymienioną zasadą interpretacyjną, powinna być zaklasyfikowana tak, jak gdyby składała się z usługi, która nadaje całości zasadniczy charakter;

- usługę, której nie można zaklasyfikować zgodnie z powyższymi zasadami, należy zaklasyfikować w grupowaniu odpowiednim dla usługi o najbardziej zbliżonym charakterze.

Zgodnie $\mathrm{z} \$ 2$ ust. 1 r.zwal. z obowiązku ewidencjonowania w danym roku podatkowym, nie dłużej jednak niż do 31 grudnia 2021 r., są zwolnieni podatnicy:

- „u których obrót zrealizowany na rzecz osób fizycznych nieprowadzących działalności gospodarczej oraz rolników ryczałtowych nie przekroczył w poprzednim roku podatkowym kwoty $20000 \mathrm{zl}^{7}$, a w przypadku podatników rozpoczynających $\mathrm{w}$ poprzednim roku podatkowym dostawę towarów lub świadczenie usług na rzecz osób fizycznych nieprowadzących działalności gospodarczej oraz rolników ryczałtowych, jeżeli obrót z tego tytułu nie przekroczył, w proporcji do okresu wykonywania tych czynności w poprzednim roku podatkowym, kwoty 20000 zł” (\$ 3 ust. 1 pkt 1 r.zwal.);

- rozpoczynający „po dniu 31 grudnia 2018 r. dostawę towarów lub świadczenie usług na rzecz osób fizycznych nieprowadzących działalności gospodarczej oraz rolników ryczałtowych, jeżeli przewidywany przez podatnika obrót z tego tytułu nie przekroczy, w proporcji do okresu wykonywania tych czynności w danym roku podatkowym, kwoty 20000 zl” (\$ 3 ust. 1 pkt 2 r.zwal.);

- „którzy dokonują dostawy towarów lub świadczą usługi zwolnione z obowiązku ewidencjonowania, wymienione w części I załącznika do rozporządzenia, w przypadku gdy udział obrotu z tytułu czynności zwolnionych z obowiązku ewidencjonowania, wymienionych w części I załącznika do rozporządzenia, w całkowitym obrocie podatnika realizowanym na rzecz osób fizycznych nieprowadzących działalności gospodarczej oraz rolników ryczałtowych [...] był

7 To znaczy bez kwoty podatku należnego (por. art. 29a ust. 6 pkt 1 u.p.t.u.). 
w poprzednim roku podatkowym wyższy niż 80\%”, tzw. udział procentowy obrotu ( $\$ 3$ ust. 1 pkt 3 r.zwal.);

- rozpoczynający „po dniu 31 grudnia 2018 r. dostawę towarów lub świadczenie usług na rzecz osób fizycznych nieprowadzących działalności gospodarczej oraz rolników ryczałtowych, jeżeli przewidywany przez podatnika udział procentowy obrotu: a) za okres pierwszych sześciu miesięcy wykonywania tych czynności, b) za okres do końca roku, w przypadku gdy okres wykonywania tych czynności w roku podatkowym jest krótszy niż sześć miesięcy będzie wyższy niż 80\%” ( $\$ 3$ ust. 1 pkt 4 r.zwal.).

Jeżeli organizacja non profit (stowarzyszenie lub fundacja) nie wykonuje czynności zwolnionych z obowiązku ewidencjonowania przy zastosowaniu kas rejestrujących lub nie korzysta ze zwolnienia podmiotowego (ze względu na wysokość osiąganego obrotu z tytułu sprzedaży na rzecz osób fizycznych nieprowadzących działalności gospodarczej lub rolników ryczałtowych), jest obowiązana - w przypadku sprzedaży na rzecz osób i podmiotów wymienionych w art. 111 ust. 1 u.p.t.u. - do ewidencjonowania obrotu i kwot podatku należnego przy zastosowaniu kas rejestrujących.

Reasumując: o obowiązkach organizacji non profit (stowarzyszenia, fundacji) w zakresie podatku od towarów i usług przesądza zakres prowadzonej przez nią działalności. W pierwszej kolejności należy odpowiedzieć na pytanie, czy dokonywanej przez organizację non profit dostawie towarów lub świadczeniu usług można przypisać charakter odpłatny. Zgodnie bowiem $\mathrm{z}$ art. 5 ust. 1 pkt 1 u.p.t.u. opodatkowaniu podatkiem od towarów i usług podlega jedynie odpłatna dostawa towarów i odpłatne świadczenie usług na terytorium kraju (por. też art. 7 i 8 u.p.t.u.). „[P]odmiot, który wykonuje wyłącznie czynności nieodpłatne, nie może być uznany za podatnika VAT (tak ETS w orzeczeniu 89/81, Staatssecretaris van Financiën v. Hong-Kong Trade Development Council). Nie wykonuje on bowiem wówczas żadnych czynności opodatkowanych. W piśmiennictwie wskazuje się, że jest jednak różnica pomiędzy działalnością a działalnością gospodarczą (B.J.M. Terra, Developments in VAT - the deduction of input tax, „International VAT Monitor” 1996/2, s. 53). Całkowity brak odpłatności eliminuje podmiot z systemu VAT, który obejmuje działalność gospodarczą, a nie wszelką działalność" Następnie, o ile organizacja non profit dokonuje odpłatnej dostawy towarów lub odpłatnego świadczenia usług w rozumieniu art. 5 ust. 1 pkt 1 u.p.t.u., należy określić:

- zakres podmiotowy realizowanych dostaw towarów lub usług (obowiązek prowadzenia kas rejestrujących dotyczy tylko sprzedaży dokonywanej na

8 A. Bartosiewicz, op. cit., pkt 24. Zob. również interpretacje indywidualne o numerach: 548621/I (sygn. 0112-KDIL2-2.4012.523.2018.3.MŁ z dnia 5 lutego 2019 r.) oraz 524532/I (sygn. 0112-KDIL2-2.4012.524.2017.2.MŁ z dnia 22 stycznia 2018 r.), https://sip.mf.gov.pl [dostęp 3 lutego 2020 r.]. 
rzecz osób fizycznych nieprowadzących działalności gospodarczej oraz rolników ryczałtowych);

- o ile zakres podmiotowy realizowanych dostaw (sprzedaży) obejmuje podmioty, o których mowa w art. 111 ust. 1 u.p.t.u.:

- kwotę uzyskiwanego obrotu ze sprzedaży na rzecz osób fizycznych nieprowadzących działalności gospodarczej lub rolników ryczałtowych, co przesądzi o możliwości skorzystania ze zwolnienia podmiotowego, o którym mowa w $\$ 2$ r.zwal. (ze względu na wysokość osiąganego obrotu), lub

- zakres przedmiotowy realizowanych czynności, co przesądzi o możliwości skorzystania ze zwolnienia przedmiotowego, o którym mowa w $₫ 3$ r.zwal.

\section{Podsumowanie}

- Obowiązek prowadzenia ewidencji sprzedaży przy zastosowaniu kas rejestrujących obejmuje wszystkich podatników podatku od towarów i usług dokonujących sprzedaży na rzecz podmiotów wskazanych $\mathrm{w}$ art. 111 ust. 1 u.p.t.u., a więc osób fizycznych nieprowadzących działalności gospodarczej oraz rolników ryczałtowych.

- Podatnikami podatku od towarów i usług są osoby prawne, jednostki organizacyjne nieposiadające osobowości prawnej oraz osoby fizyczne wykonujące samodzielnie działalność gospodarczą zdefiniowaną w art. 15 ust. 2 u.p.t.u., bez względu na cel i rezultat takiej działalności.

- Z definicji działalności gospodarczej sformułowanej do celów podatku od towarów i usług (art. 15 ust. 1 i 2 u.p.t.u.) wynika, że za działalność gospodarczą uznaje się wszelką aktywność danego podmiotu, o której mowa w art. 15 ust. 2 u.p.t.u., bez względu na cel i rezultat takiej działalności.

- Organizacje non profit, w tym stowarzyszenia i fundacje, o ile dokonują odpłatnej dostawy towarów i odpłatnego świadczenia usług na terytorium Polski, należy uznać za podatników podatku od towarów i usług, nawet jeżeli nie działają w celu osiągnięcia zysku.

- O ile organizacja non profit (stowarzyszenie, fundacja) dokonuje sprzedaży na rzecz osób fizycznych nieprowadzących działalności gospodarczej lub rolników ryczałtowych, jest obowiązana - pomimo braku zarobkowego charakteru działalności (sprzedaży) lub wpisania działalności gospodarczej do statutu - prowadzić ewidencję sprzedaży przy zastosowaniu kas rejestrujących, chyba że korzysta ze zwolnienia wynikającego z przepisów wykonawczych do ustawy o podatku od towarów i usług.

- Organizacja non profit (stowarzyszenie, fundacja) może skorzystać ze zwolnienia z obowiązku prowadzenia kas rejestrujących wyłącznie na zasadach określonych w rozporządzeniu Ministra Finansów w sprawie zwolnień z obowiązku prowadzenia ewidencji przy zastosowaniu kas rejestrujących, o ile speł- 
nia zawarte w nim warunki (zwolnienie podmiotowe ze względu na wysokość osiągniętego obrotu lub przedmiotowe ze względu na rodzaje wykonywanych czynności).

\section{Bibliografia}

Bartosiewicz A., Komentarz do art. 15 ustawy o podatku od towarów i usług, LEX. 